\title{
ПАРЦЕЛЯЦІЯ ЯК СИНТАКСИЧНИЙ ЗАСІБ РЕПРЕЗЕНТАЦІЇ ПОНЯТТЯ “ВІДСУТНІСТЬ” У ПОВІСТІ С. Д. ДОВЛАТОВА «ЗОНА»
}

Статтю присвячено проблемі репрезентації поняття “відсутність" на синтаксичному рівні. Дослідження здійснено на матеріалі повісті С. Д. Довлатова «Зона». Мета роботи - встановлення особливостей функиіонування париеляції як синтаксичного засобу репрезентації поняття "відсутність". Зроблено висновок, що досліджуване поняття на синтаксичному рівні може бути репрезентоване через париеляцію, а нецілісні структури є характерною рисою авторського дискурсу С. Д. Довлатова. Париельовані синтаксичні конструкиї уможливлюють реалізацію в тексті невербальних засобів вираження поняття "відсутність".

Ключові слова: когнітивна тінгвістика, поняття “відсутність", дискурс, синтаксис, париеляиія.

Kornieieva O. Parceling as a Syntactic Means of Representation of the Concept "Absence" in S. D. Dovlatov's Novel "The Zone». In the works devoted to the syntactic level of the language system according to various criteria, attention is drawn to the fact that paradigmatic parameters exist only in the binary opposition presence vs absence. The absence of one of the paradigm members becomes significant only in its relation to the presence. Philologists pay more attention to the presence of certain syntactic indicators that are fixed in the language and function in speech. At the same time, the role of the absence of certain elements is often equally important for the analysis and explanation of the text. Therefore, in our opinion, it is interesting to turn to the analysis of parceled constructions in discourse and explanation from the cognitive point of view of the concept "absence", which is represented by syntactic units, namely parceling.

Parceled syntactic constructions play an important role in modern cognitive syntax studies. They acquire special significance in the author's discourse since they reflect the characteristic features of mental processes in a writer's mind. The parceling attracts the attention of Ukrainian scholars, but the role of this syntactic construction in the representation of the concept "absence" has not been analyzed in detail by linguists, which determines the relevance of our topic. The aim of the study is to identify the features of functioning of parceling as a syntactic means of representing the concept "absence" on the material of S. D. Dovlatov's novel «The Zone» («Зона»).

Based on the assertion that the concept "absence" is one of the primary concepts in human subconsciousness, it is realized in language and speech not only in lexical, 
but also in grammatical units, and above all, at the syntactic level. These facts determined the task: to analyze parceled syntactic constructions as a means of representing the concept "absence" in the text of S. D. Dovlatov's novel "Zone» in terms of cognitive syntax.

The concept "absence" at the syntactic level has various manifestations. Namely: it can be presented as parceled syntactic constructions, which due to the lack of integrity and completeness of the sentence, demonstrate non-verbal means of expressing the concept "absence", such as intonation or pause; variability of actions or inaction; realism of memories in which part of the events disappears. Also, simple onemember sentences and predicative constructions with zero verb-predicates are widely represented in parceling. Missing members of the sentence indicate the peculiarities of the author's worldview, make it possible to emphasize the most important ones. One-member impersonal sentences can be interpreted as a lack of freedom of choice imposed by someone or something.

Key words: cognitive linguistics, the concept "absence", discourse, syntax, parceling.

\section{Вступ}

У дослідженнях синтаксичного рівня мовної системи за різними критеріями привертає увагу той факт, що парадигмальні параметри існують в бінарній опозиції наявність vs вiдcymність. Відсутність одного із членів парадигми набуває значущості в кореляції з наявністю. Філологи все більше звертають увагу на наявність тих чи тих синтаксичних показників, що зафіксовані в мові та функціонують у мовленні. Водночас роль відсутності певних елементів часто має не менше значення для аналізу тексту, тому, на наш погляд, цікаво звернутися до аналізу парцельованих конструкцій у дискурсі й пояснення в когнітивному аспекті поняття “відсутність”, що репрезентоване синтаксичними одиницями, зокрема парцеляцією.

Парцельовані синтаксичні конструкції відіграють важливу роль у сучасних дослідженнях когнітивного синтаксису. Особливого значення вони набувають в авторському дискурсі, оскільки відображають характерні риси ментальних процесів у свідомості письменника. Парцеляція привертає увагу як українських (О. О. Скоробогатова (Скоробогатова, 1990)), так і зарубіжних дослідників (Ю. В. Богоясловська (Богоясловська, 2003), Т. Г. Сербіна (Сербіна, 1988), Л. В. Щерба (Щерба, 1974)), але роль цієї синтаксичної конструкції в репрезентації поняття “відсутність” детально проаналізована не була, що й зумовлює 
потребу подальшого вивчення обраного аспекту та актуальність нашого дослідження.

Мета цієї наукової розвідки - встановлення особливостей функціонування парцеляції як синтаксичного засобу репрезентації поняття “відсутність” на матеріалі повісті С. Д. Довлатова «Зона». На основі твердження про те, що поняття “відсутність” виступає одним із первинних у підсвідомості людини, робимо припущення, що воно зреалізовано в мові й мовленні не лише в лексиці, а й у граматиці, передусім на синтаксичному рівні. Це зумовило завдання нашої роботи: 1) описати особливості реалізації поняття “відсутність” мовними, зокрема синтаксичними, одиницями; 2) проаналізувати парцеляційні синтаксичні конструкції як засоби репрезентації поняття “відсутність” у тексті повісті «Зона» С. Д. Довлатова в аспекті когнітивного синтаксису.

\section{Методи дослідження}

Для узагальнення інформації про парцельовані синтаксичні конструкції було використано метод аналізу літературних джерел; описовий метод застосовано для пояснення особливостей будови й функціонування парцеляцій; прийом інтерпретації ролі парцеляції у формуванні поняття “відсутність”, метод концептуального аналізу для моделювання структури досліджуваного поняття.

\section{Виклад основного матеріалу}

Мовна система грунтується на біполярності понять наявність vs вiдcymність. Зокрема, на синтаксичному рівні це репрезентовано в таких протиставленнях складників простих речень: залежно від наявності конкретних членів речення їх поділяють на поширені (наявні другорядні члени) та непоширенні, повні (два головні члени) та неповні (один із головних членів). Також речення можуть бути ускладненими (за наявності вставних конструкцій, однорідних членів речення, звертань та ін.) і неускладненими (з відсутністю додаткових синтаксичних елементів у реченні). Частотність конкретного типу речення визначається особливістю селекції мовних засобів, що уможливлює виявлення причин і способів репрезентації поняття “відсутність” у творах С. Д. Довлатова. В авторському дискурсі відбір 
наявних у системі мовних засобів відбувається свідомо, у чому виявляються авторська уява та креативні здібності.

Науковці трактують поняття “дискурс” досить широко: і як комунікативний процес, і як його результат. О. О. Селіванова визначає мовний дискурс як зв'язний текст у контексті численних супровідних фонових чинників - онтологічних, соціокультурних, психологічних тощо (Селіванова, 2010: 121). Це спонукає до висновку про необхідність усебічного аналізу авторського тексту крізь призму основних подій життя письменника й чинників, що вплинули на розвиток його особистості. Безперечно, «мислення та сприйняття людиною довкілля завжди визначаються іiі буденним життям, це абстрагування грунтується на повсякденному досвіді. Тому рутинне життя, тривіальні потреби є важливим аргументом для розуміння зв'язку лексичної семантики й граматичної реалізації слова з концептуальною системою мови» (переклад наш - О. К.) (Радчук, 2018: 80).

Проза С. Д. Довлатова обрана для нашого дослідження не випадково. Письменник - людина з непростою долею. Він пережив багато емоційних потрясінь: службу наглядачем у місцях обмеження волі, розлучення, неможливість професійної реалізації на Батьківщині, еміграцію. Усі ключові моменти біографії письменника пов’язані з утратою зони комфорту, звичного життєвого середовища, що призвело до частотної реалізації поняття “відсутність” у його творах на всіх мовних рівнях. Сприяла цьому й автобіографічність творчості письменника, що пронизана справжніми емоціями. Повість «Зона» являє собою уривки, які збереглися від спогадів про службу С. Д. Довлатова в Радянській армії. Назва «Зона» уособлює переломний момент у житті й свідомості як ув'язнених, так і солдатів. Потрапляючи до місця обмеження волі, людина втрачає все, до чого звикла, зокрема близьких, соціальні зв'язки, свободу вибору та пересування, почуття безпеки й власної гідності. Через те, що поняття “відсутність” закріплюється у свідомості носія мови залежно від його життєвого досвіду, воно не може не впливати на авторський дискурс. Це можемо спостерігати в контекстах твору, залученого до аналізу. Численні приклади відсутності одного з головних членів речення, непоширенні речення, використання такої синтаксичної конструкції, як парцеляція, виявляють ознаки індивідуального стилю та вказують на особливості світосприйняття автора. Поняття “відсутність” є одним з визначальних 
у формуванні картини світу письменника і як наслідок - його авторського дискурсу.

Звертаючись до поняття “відсутність”, констатуємо такі його особливості. Це насамперед мультидисциплінарне явище, яке представляє собою частину бінарної опозиції наявність vs відсутність, що входить до методології багатьох дисциплін: філософії, педагогіки, лінгвістики, психології тощо. Це абстрактне поняття є формою мислення і реалізується в мові в словах, словосполученнях, реченнях. О. В. Радчук уважає, що “відсутність” належить до базових когнітивних понять, оскільки впливає на формування людської мови як феномена (Радчук, 2019: 31), відображає конкретні розумові процеси, що вербалізуються через мовлення засобами різних мовних рівнів. За О. О. Потебнею, граматика - це наука, складник одного з витворів діяльності людського розуму (Потебня, 1958: 12), тому, зокрема, у синтаксисі поняття “відсутність” має свої особливості реалізації.

Поняття “відсутність” формується на глибинному рівні й, як наслідок, утілюється і вербальними засобами (усі рівні мовної системи), і невербальними. У процесі спілкування для вираження експресії мовці використовують інтонацію, жести, міміку. У літературному творі автор має можливість лише словесно зобразити вираз обличчя або рухи героя. У повісті «Зона» С. Д. Довлатова фіксуємо значну кількість діалогів, однак опис невербальних знаків переважно не репрезентований. Для вираження експресивності автор використовує засоби комунікативного синтаксису. Сегментовані, парцельовані конструкції, паралелізми $є$ найбільш уживаними в досліджуваному тексті. Поняття “відсутність” С. Д. Довлатов репрезентує шляхом обірваності речення, що забезпечує імітацію живого мовлення.

Парцеляція виступає одним із найчисленніших експресивних синтаксичних засобів у текстах творів письменника. Одним із перших лінгвістів, який почав використовувати термін “парцеляція” для позначення явища розчленування єдиної граматичної конструкції, був О. Ф. Єфремов. Існує декілька визначень цього поняття, одним із загальноприйнятих $є$ трактування О. О. Скоробогатової: парцеляція - це «текстове за природою явище, яке знаходить своє вираження у висловлюваннях, що побудовані за моделями речень різних типів, членованих на декілька інтонаційно відокремлених відрізків-фраз, які мають певну комунікативну самостійність» (переклад наш - О. К.) 
(Скоробогатова, 1990: 8). 3 вищезазначеного випливає, що парцеляція представляє собою імітацію спонтанного мовлення, яке відбувається паралельно з процесом мислення.

Парцеляція в повісті «Зона» С. Д. Довлатова характеризується моносуб'єктністю. Зазвичай розчленовують прості речення, унаслідок чого виокремлюється один із їх членів. У таких випадках поняття “відсутність" зреалізовано під час членування і репрезентовано відсутністю цілісності трансляції інформації. Цей прийом використовують для підкреслення реми висловлювання. Парцеляція може бути репрезентована різними членами речення. Наприклад, у тексті, що досліджуємо, представлено такі її типи:

а) парцеляція-присудок: Он мог курить, сидя на гимнастических брусьях. Играть в домино под хриплье звуки репродуктора. Или, наконеи, осваивать ротную библиотеку... (Довлатов, 1999: 26); Егоров вернулся с охапкою дров. Обрушил их возле печки (Довлатов, 1999: 82); Катя сунула ноги в остывшие чуни. Вышла на кухню. Постояла немного, кутаясь в синий халат (Довлатов, 1999: 81); Ключи Балодис иелый день носил в руках. Засыпая, привязывал их шпагатом ксвоему детородному органу (Довлатов, 1999: 32);

б) парцеляція-додаток: Однако голодные псы рычали и на солдат в зеленых телогрейках. И на сверхсрочников в офицерских шинелях. И на самих офииеров. И даже на Воликова с Пахапилем (Довлатов, 1999: 26);

в) парцеляція-означення: Лагерь учреждение советское - по духу. По внутренней сути ... (Довлатов, 1999: 12); Ведь где-то есть иная жизнь (какая?)... Там земляника, костры и песни... И табиринть тропинок, пересеченных корнями сосен... И реки, и люди, ожидающие переправы... (Довлатов, 1999: 82).

Членовані речення з однорідними присудками створюють найчисленнішу групу парцелятів у повісті: Я не коллекционировал марок. Не оперировал дождевых червей. Не строил авиамоделей. Более того, я даже не очень любил читать. Мне нравилось кино и безделье (Довлатов, 1999: 15). Відсутність підметів акцентує увагу на діях персонажа, що демонструє особливість світосприйняття автора, указує на те, що С. Д. Довлатов - людина дії і передусім сприймає та оцінює представників свого оточення за їхніми вчинками. Завдяки парцеляції однорідних речень письменник показує альтернативи дій або 
бездіяльності (мог курить, играть, осваивать; не коллекиионировал, не оперировал, не строил), породжує певний емоційний настрій, надає тексту експресивного забарвлення. Ю. В. Богоясловська відзначає, що атрибутивні відношення в парцеляції мають предикативний характер. У російській мові в 90\% випадків парцеляти набувають значення предикативних доповнень, до яких також належать дієприкметникові, дієприслівникові та інфінітивні звороти (Богоясловская, 2003), що й підтверджують проаналізовані приклади.

У тексті «Зони» часто трапляється поєднання парцеляції із синтаксичним паралелізмом: Возьмите тагерную живопись. Если это пейзаж, то немыслимо знойный, андолузской расиветки. Если натюрморт, то преисполненный калорий (Довлатов, 1999: 54). Повторення не лише посилює експресивність, а й акцентує увагу на основній думці висловлювання. Відсутність нових структур дає реципієнтові змогу зосередитися на конкретному міркуванні. Фіксуємо різноманітні варіанти висловлювань, у яких відсутність цілісності картини сприйняття репрезентується парцеляцією. Відзначимо, що паралельні конструкції притаманні авторському дискурсу С. Д. Довлатова. Паралельні парцеляти дають змогу письменникові більш яскраво передати психологічний стан персонажів, їхні емоції, сприйняття навколишнього світу й процес мислення.

У прикладах синтаксичного паралелізму вживаються конструкції з нульовим дієсловом-предикатом (тобто в таких конструкціях не вживається дієслово-предикат, значення якого можна зрозуміти з парадигми подібності): Напомню вам, что лагерь является типично советским учреждением. И не только по своему административно-хозяйственному устройству. Не только по внедряемой сверху идеологии. Не только в силу привычных формальностей (Довлатов, 1999: 112). У другому й третьому реченнях наведеного уривку значення дієслово-предиката можемо зрозуміти з основного висловлювання.

С. Д. Довлатову властиві короткі односкладні речення. Наприклад: Свисаюшие темные одеяла. Ряды обернутых портянками сапог. Лозунги и такаты на стенах (Довлатов, 1999: 33). Вспомните подземные столичные мозаики ... Грузины, литовцы, армяне... Крупныци и мелкий рогатьй скот... Ведь это те же бизоны! (Довлатов, 1999: 112). Наведенні парцеляти - номінативні, що підкреслює 
відсутність дій. В обох прикладах парцеляції виконують функцію уточнення. Відсутність предикативності, що виражає в реченні події та використовується для позначення часу й певного адресанта, розмиває межі речень та створює ефект безсистемного накопичення. Дієслово $є$ істотною ознакою речення, оскільки пов'язане з граматичними категоріями модальності, особи, часу, що виражаються особовими формами. Ці ідеї заклав відомий український лінгвіст О. О. Потебня, який уважав первинними не імена, а саме дієслова. Учений стверджував, що граматично оформлені слова, які використовуються на позначення предметів (іменники), дій (дієслова), властивостей (прикметники) передають зміст речення. I кожне слово $є$ носієм певної ознаки, однак виражають вони їі по-різному (Потебня, 1958: 19). Загальновідомо, що дієслово виступає ядром синтаксичної структури речення. Тож відсутність запрограмованих дієсловом членів речення вказує на особливості світосприйняття автора.

Репрезентацією поняття “відсутність” у тексті на синтаксичному рівні можемо вважати конструкції з нереалізованою валентністю, у яких словесно не позначені певні члени потрібні з огляду граматики або семантики. Проаналізуємо неповні речення, що входять до складу парцеляції: Мечтали о свободе, пели и клялись... А вышли - и тайга до горизонта... (Довлатов, 1999: 47). У наведеному прикладі немає підмета - суб'єкта дії: (хто?) мечтали, пели и клялись; вышли (хто?). Дієслово вышли вимагає після себе обставину місця (вийшли куди?). Проаналізуємо семантику слова выйти. У тлумачному словнику C. I. Ожегова подано таке визначення (подаємо мовою оригіналу, щоб уникнути двозначності): 1. Уйдя, удалившись, оставить пределы чего-н., покинуть что-н.; оказаться пущенным, выброшенным, вытечь. 2. Уйдя откуда-н., появиться, оказаться где-н. 3. перен., из чего. Перестать находиться в каком-н. состоянии, положении (Ожегов, \& Шведова, 2006: 98). У цьому разі пропущені члени речення вказують, що в картині світу С. Д. Довлатова за семантикою слова выйти закріпилося саме значення 'залишити межі чогось' (зони), тож вышли (хто?) зеки; і не вимагає вербального пояснення. Повтор свідчить про відсутність віри письменника як громадянина Радянського Союзу в справедливість судової системи.

Випадки відсутності суб'єкта дії трапляються частіше в основному висловлюванні в листуванні автора з редактором, оскільки 
використовуються притаманні листам означено-особові речення, у яких головний член виражається другою особою однини: Bcmpemите на машине - хорошо. Нет, доберусь сам (Довлатов, 1999: 47); або першою особою однини чи множини в автобіографічних описах С. Д. Довлатова: Живу в отеле «Куртис» с множеством разнообразных увеселений. Есть бар. Есть бассейн (Довлатов, 1999: 67). У деяких синтаксичних конструкціях немає підмета ні в основному висловлюванні, ні в парцелятах: Налоговое ведомство обманьввем. В конкурентов постреливаем. В газетах печатаем бог знает что... (Довлатов, 1999: 80). Парцеляти репрезентовані означено-особовими реченнями, у яких присудок стоїть у першій особі множини. Це демонструє те, що С. Д. Довлатов не відокремлює себе від інших емігрантів з Радянського Союзу, показує колективну духовну єдність. Цікаво, що парцеляти в наведених прикладах - теж неповні або непоширені речення.

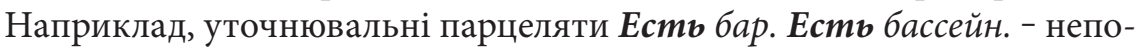
ширені речення. Зауважимо, що поняття “відсутність” зреалізоване шляхом уникнення другорядних членів речення та сприяє зосередженню уваги читача на дії. Фіксуємо інший цікавий приклад парцельованої конструкції, яка демонструє особливості авторського дискурсу: Посмотрите, что делается в эмиграици. Брайтонский неп - в разгаре. Полно хулиганья. (Довлатов, 1999: 80). Основне висловлювання складнопідрядне речення, головна частина якого означено-особова, представлена формою другої особи множини. Підрядна ж - безособове речення, яке ніби знімає відповідальність з членів емігрантської спільноти за те, що там відбувається. Водночас письменник не відчуває себе частиною спільноти, що було зрозумілим з іншого прикладу. Відсутність дієслів у парцелятах підсилює враження безвідповідальності й бездіяльності виходців із СРСР. Вищеперераховане створює образ автора не як стороннього спостерігача, а як активного учасника повісті. С. Д. Довлатов свідомо використовує означено-особові речення для посилення впливу на читача, текст набуває форми діалогу з реципієнтом, що починає себе відчувати причетним до подій. Насправді, листи до редактора в тому вигляді, у якому вони подані у творі, - художня вигадка письменника, створена для встановлення зв'язку з читачем. Для цього письменник репрезентує поняття “відсутність” на синтаксичному рівні у формі парцеляції й обірваних або неповних речень у його складі. В аспекті когнітивного синтаксису 
матеріали для аналізу репрезентації поняття “відсутність” в авторському дискурсі можна знайти у складі парцеляції в односкладових безособових реченнях, у яких дія виступає незалежно від суб'єкта, репрезентована як неконтрольована зовнішня або внутрішня сила. На підгрунті дослідження саме цього виду односкладних речень у російській мові польський лінгвіст А. Вежбицька зробила висновок про безвідповідальність носіїв російської мови (Вежбицька, 1999: 300). Із цим твердженням важко погодитися в масштабі цілої нації, але в межах аналізу окремого твору тенденція до безособових речень може свідчити про вимушену бездіяльність, що актуально для повісті «Зона»: Было очень рано. В прихожей гулко тикали ходики (Довлатов, 1999: 82). ...Публика у нас бесподобная. Ворюги да хулиганы... Какой уж там рай...Таких и в дисбат не примут (Довлатов, 1999: 30). У реаліях місця обмеження волі не лише ув'язнені живуть за низкою сурових правил, але й охоронці. Можемо стверджувати, що відсутність свободи у творі С. Д. Довлатова виражається безособовими реченнями. Можливо, певною мірою в письменника когнітивне, несвідоме закладене від народження, що знайшло реалізацію у використанні безособових речень.

\section{Висновки}

Висновковуємо про те, що поняття “відсутність” на синтаксичному рівні має різноманітні вияви, зокрема може репрезентуватися в парцельованих синтаксичних конструкціях. Завдяки нецілісності й незавершеності речень вони демонструють такі невербальні форми його вираження, як інтонація, паузація. Також парцеляцію можемо трактувати як репрезентацію понять дія vs бездіяльність. Поняття “відсутність", утілене на синтаксичному рівні, виражає реалістичність спогадів, у яких зникає частина подій. Крім того, у складі парцеляції широко представлені односкладні речення та предикативні конструкції з нульовим дієсловом-предикатом. Матеріально не виражені члени речення свідчать про особливості світосприйняття автора, уможливлюють виділення найсуттєвішого. Уживання односкладних безособових речень можна трактувати як вираження відсутності свободи вибору, нав’язані кимось або чимось дії.

Поняття “відсутність” має численні репрезентації на синтаксичному рівні в тексті повісті С. Д. Довлатова «Зона», що свідчить про 
ключову роль цього абстрактного поняття в авторському дискурсі письменника.

Проблематика, актуалізована в статті, потребує подальшої розробки на матеріалі інших творів з літературного набутку письменника.

\section{ЛІТЕРАТУРА}

1. Бартминський, Е. (2005). Языковой образ мира: очерки по этнолингвистики. Москва: Индрик. 2. Богоясловская Ю. В. Парцеляция в русском и французском языках: структурно-семантические особенности. (Дис. ... канд. филол. наук). Екатеринбург: Урал. гос. пед. ун-т. 3. Вержбицька, А. (1999). Семантичні універсаліі й опис мов. Київ: Логос. 4. Довлатов, С. Д. (1999). Собрание сочинений. (Т. 2). СанктПетербург: Азбука. 5. Кацнельсон, С. Д. (1972). Типология языка и речевое мьишление. Ленинград: Наука. 6. Ожегов, С. И., \& Шведова, Н. Ю. (2006). Толковый словарь русского языка. Москва: АТЕМП. 7. Потебня, А. А. (1958). Из записок по русской грамматике. (Т. I-II.) Москва: Учпедгиз. 8. Радчук, О. В. (2018). Когнитивный подход к изучению взаимовлияния языков при утрате контактного проживания. Коммуникативное пространство Беларуси. Тезисы Междунар. науч. конф. (с. 79-82). Минск: МГЛУ. 9. Радчук, О. В. (2019). Лингвокогнитивная репрезентация понятия "отсутствия” в русском языке. Харьков: Юрайт. 10. Селіванова, О. О. (2010). Лінгвістична енциклопедія. Полтава: Довкілля-К. 11. Сербина, Т. Г. (1988). Парцелляция как особое синтаксическое явление в языке современных газет. (Дис. ... канд. филол. наук). Львов: ЛДУ имени Ивана Франко. 12. Скоробогатова, Е. А. (1990). Парцелляция полипредикативного высказывания в современном русском языке. (Автореф. дис. ... канд. филол. наук). Харьков: ХНПУ имени Г. С. Сковороды. 13. Щерба, Л. В. (1957). Избранные работы по русскому языку. Москва:Учпедгиз.

\section{REFERENCES}

1. Bartmins'kij, E. (2005). Yazykovoj obraz mira: ocherki po e'tnolingvistiki. [The linguistic image of the world: essays on Ethnolinguistics]. Moskva: Indrik [in Russsian]. 2. Bogoyaslovskaya, Yu. V. Parcelyaciya v russkom i francuzskom yazykax: strukturno-semanticheskie osobennosti [Parcels in Russian and French: structural and semantic features]. Candidate's thesis. Ekaterinburg: Ural. gos. ped. un-t [in Russian]. 3. Verzhbytska, A. (1999). Semantychni universalii y opys mov [Semantic universals and description of languages]. Kyiv: Lohos [in Ukrainian]. 4. Dovlatov, S D. (1999). Sobranie sochinenij [Collected edition]. (Vol. 2). Sankt-Peterburg: Azbuka [in Russian]. 5. Kacnel'son, S. D. (1972). Tipologiya yazyka i rechevoe myshlenie [Typology of language and speech thinking]. Leningrad: Nauka [in Russian]. 6. Ozhegov, S. I., \& Shvedova, N. Yu. (2006). Tolkovyj slovar' russkogo yazyka [Dictionary of the Russian language]. Moskva: ATEMP [in Russian]. 7. Potebnya, A. A. (1958). Iz zapisok po russkoj grammatike [Some notes on Russian grammar]. (T. I-II.) Moskva: Uchpedgiz [in Russian]. 8. Radchuk, O. V. (2018). Kognitivnyj podhod k izucheniyu vzaimovliyaniya yazykov pri utrate kontaktnogo prozhivaniya [A cognitive approach to the study of the mutual influence of languages in case of the loss of contact residence]. Kommunikativnoe prostranstvo Belarusi. Tezisy Mezhdunar. nauch. konf. - Communicative space of Belarus. 
Abstracts of the International Scientific Conference (pp. 79-82). Minsk: MGLU [in Russian]. 9. Radchuk, O. V. (2019). Lingvokognitivnaya reprezentaciya ponyatiya "otsutstviya" $v$ russkom yazyke [Linguo-cognitive representation of the concept of "absence" in the Russian language]. Xar'kov: Yurajt [in Russian]. 10. Selivanova, O. O. (2010). Linhvistychna entsyklopediia [Linguistic encyclopedia]. Poltava: Dovkillia-K [in Ukrainian]. 11. Serbina, T. G. (1988). Parcellyaciya kak osoboe sintaksicheskoe yavlenie v yazyke sovremennyx gazet [Parcelling as a special syntactic phenomenon in the language of modern newspapers]. Candidate's thesis. L'vov: LDU imeni Ivana Franko [in Russian]. 12. Skorobogatova, E. A. (1990). Parcellyaciya polipredikativnogo vyskazyvaniya $\mathrm{v}$ sovremennom russkom yazyke [Parcellation of polypredicative utterances in modern Russian]. Candidate's thesis. Xar'kov: XNPU imeni G. S. Skovorody [in Russian]. 13. Shherba, L. V. (1957). Izbrannye raboty po russkomu yazyku [Selected works on the Russian language]. Moskva: Uchpedgiz [in Russian].

Корнєєва Олена Миколаївна - аспірант кафедри зарубіжної літератури та слов'янських мов, Харківський національний педагогічний університет імені Г. С. Сковороди; вул. Індустріальна, 4, м. Краматорськ, 84307, Україна.

Tel.: +38-095-178-05-88

E-mail: helenkorneev@gmail.com

http://orcid.org/0000-0003-1023-7135

Kornieieva Olena Mykolaivna - Postgraduate Student at The Department of Foreign Literature and Slavic Languages, H. S. Skovoroda Kharkiv National Pedagogical University; 4 Industrialna Str., Kramatorsk, 84307, Ukraine.

Надійшла до редакції 26 березня 2021 року

\section{CITATION}

ДСТУ 8302:2015: Корнєєва О. М. Парцеляція як синтаксичний засіб репрезентації поняття "відсутність" у повісті С. Д. Довлатова «Зона». Лінгвістичні дослідження: зб. наук. пр. Харк. нац. пед. ун-ту імені Г. С. Сковороди. Харків, 2021. Вип. 54. Ч. II. C. 45-56. DOI: https://doi.org/10.34142/23127546.2021.54.2.05

APA: Корнєєва, О. М. (2021). Парцеляція як синтаксичний засіб репрезентації поняття "відсутність" у повісті С. Д. Довлатова «Зона». Лінгвістичні дослідження, 54 (II), 45-56. DOI: https://doi.org/10.34142/23127546.2021.54.2.05 